\title{
Testiculaire aandoening van seksuele differentiatie (78,XX $S R Y$-negatief) bij een vrouwelijke Franse buldog
}

\author{
Testicular disorder of sex development (78,XX SRY-negative) \\ in a female French bulldog
}

\author{
${ }^{1}$ A. Van Cleven, ${ }^{2}$ E. Wydooghe, ${ }^{3}$ L. Van Brantegem, ${ }^{4}$ I. Szczerbal, ${ }^{4} M$. Stachowiak, \\ ${ }^{4}$ M Switonski, , ${ }^{1}$ H. de Rooster \\ ${ }^{1}$ Vakgroep Geneeskunde en Klinische Biologie van de Kleine Huisdieren, Faculteit Diergeneeskunde, \\ UGent, Salisburylaan 133, B-9820 Merelbeke \\ ${ }^{2}$ Vakgroep Verloskunde, Voortplanting en Bedrijfsdiergeneeskunde, Faculteit Diergeneeskunde, \\ UGent, Salisburylaan 133, B-9820 Merelbeke \\ ${ }^{3}$ Vakgroep Pathologie, Bacteriologie en Pluimveeziekten, Faculteit Diergeneeskunde, \\ UGent, Salisburylaan 133, B-9820 Merelbeke \\ ${ }^{4}$ Department of Genetics and Animal Breeding, Poznan University of Life Sciences, \\ Wolynska 33, 60-637 Poznan \\ vanclevenalexia@gmail.com
}

\section{AMENVATTING}

Een tien maanden oude, vermeend vrouwelijke, intacte Franse buldog werd op de Faculteit Diergeneeskunde te Merelbeke (UGent) aangeboden met een vergrote clitoris en purulente vaginale uitvloei. Als therapie werd voorgesteld om de vergrote clitoris te verwijderen om verdere irritatie te vermijden en tegelijkertijd een gonadectomie uit te voeren aangezien de eigenaars geen fokplannen hadden. Intraoperatief werd een afwijkende genitaaltractus vastgesteld, waarbij macroscopisch een normaal uitziende baarmoeder aanwezig was maar waarbij de gonaden testes leken in plaats van ovaria. Histologisch onderzoek van het verwijderde weefsel toonde aan dat het inderdaad over bilaterale testes aansluitend op een normale baarmoeder ging. Karyotypering en de moleculaire analyse van het $S R Y$-gen resulteerden in een $78, \mathrm{XX} S R Y$-negatief karyotype. Bij de Franse buldog werd bijgevolg finaal een 78,XX $S R Y$-negatief testiculaire aandoening van seksuele differentiatie, i.e. "disorder of sex development" (DSD) gediagnosticeerd.

\begin{abstract}
A presumably female intact French bulldog of ten months old was presented to the Faculty of Veterinary Medicine of the Ghent University with an enlarged clitoris and purulent vaginal discharge. It was suggested to remove the enlarged clitoris as to avoid further irritation and to perform a gonadectomy at the same time, since the owners were not planning to breed with the dog. An abnormal reproductive tract was observed during surgery. A normal uterus was present, but both gonads resembled testes. Histologic examination of the resected tissues confirmed the presence of bilateral testes in combination with a normal uterus. Karyotyping and molecular analysis of the $S R Y$-gene resulted in a 78,XX SRYnegative karyotype. The French bulldog was diagnosed with a 78,XX SRY-negative testicular disorder of sex development (DSD).
\end{abstract}

\section{INLEIDING}

Hermafroditisme of interseksualiteit bij huisdieren is zeldzaam, met uitzondering van freemartinisme bij runderen (Hare, 1976; Volpe et al., 2000; Poth et al., 2010). Er zijn geen exacte prevalentiecijfers voorhanden.
Een interseks is een individu met genitalia die eigenschappen van beide geslachten hebben (Hare, 1976; Alam, 2007). In de literatuur is er geen eenduidige manier om interseksen in te delen. In eerste instantie is er de klassieke indeling. Deze gebruikt de termen ware hermafrodiet, mannelijke pseudohermafrodiet en vrouwelijke pseudohermafrodiet (Hare, 
1976; Poth et al., 2010; Bigliardi et al., 2011). Ware hermafrodieten hebben zowel ovariële als testiculaire weefsels. Dit kan in drie combinaties: testis met contralateraal ovarium, bilaterale ovotestis of unilaterale ovotestis met contralateraal ovarium of testis (Hare, 1976; Poth et al., 2010). Een mannelijke pseudohermafrodiet heeft testes met een vrouwelijk fenotype. Een vrouwelijke pseudohermafrodiet heeft ovaria met een mannelijk fenotype (Hare, 1976; Alam, 2007). Deze klassieke manier van indelen is enkel gebaseerd op de gonadale constitutie (Poth et al., 2010), hoewel soms ook het chromosomale profiel in rekening wordt gebracht (Meyers-Wallen, 1999; Lyle, 2007). Een tweede manier van indelen van interseksen is op basis van de etiologie (Poth et al., 2010; Lyle, 2007). De normale seksuele ontwikkeling is een opeenvolging van drie stadia. Ter hoogte van deze drie stadia kunnen fouten gebeuren die resulteren in een interseks. Zo worden drie categorieën toegekend: chromosomale, gonadale en fenotypische aandoeningen.

In de humane geneeskunde werd in 2006 de zogenaamde Chicago Consensus voorgesteld, (Lee et al., 2006). Eerst en vooral werd de benaming interseks vervangen door "aandoening van seksuele ontwikkeling' ("disorders of sex development" (DSD)) (Pasterski et al., 2010). Ook deze indeling bestaat uit drie categorieën: sekschromosoom DSD, XY DSD en XX DSD (Lyle, 2007). De eerste groep "sekschromosoom DSD" komt overeen met chromosomale aandoeningen. Individuen in deze groep hebben een afwijking in het aantal of de structuur van de geslachtschromosomen. De tweede groep "XY DSD" omvat onder andere individuen met een afwijkende testiculaire dysgenesis, i.e. een gebrekkige aanleg of ontwikkeling van de testes, en individuen met het "persistent müllerian duct syndrome". XX DSD hebben een vrouwelijk karyotype, meestal een vrouwelijk fenotype, geen $S R Y$-gen en vaak testes of ovotestes. "XX sex reversal" is een voorbeeld van deze laatste groep (MeyersWallen, 2011; Switonski, 2014). In 2011 werd voorgesteld om ook in de diergeneeskunde deze nieuwe nomenclatuur te hanteren om de communicatie tussen dierenartsen en onderzoeksgroepen onderling te verbeteren (Meyers-Wallen, 2011).

\section{CASUISTIËK}

Een tien maanden oude, vermeend vrouwelijke, intacte Franse buldog werd op de Faculteit Diergeneeskunde te Merelbeke (UGent) aangeboden met een vergrote clitoris. Op het moment van de aankoop was de hond acht weken en puilde de clitoris al een beetje uit de vulva. Sindsdien vergrootte de clitoris geleidelijk aan. In de laatste maand vóór de consultatie was ze sterk vergroot en was er een groengele, vaginale uitvloei. De hond was nog niet loops geweest. Verder had de hond af en toe diarree door een Giardia-infectie die behandeld werd met metronidazole (Flagyl®, Sanofi-Aventis, Canada) $12,5 \mathrm{mg} / \mathrm{kg}$ tweemaal daags.
Bovendien had de hond in het verleden kennelhoest en een Demodex-infectie doorgemaakt, maar beide werden succesvol behandeld. Er is geen informatie bekend over het moederdier, maar de zus van de hond vertoont geen abnormaliteiten.

Tijdens het algemeen klinisch onderzoek maakte de hond een alerte algemene indruk en werd er geen verhoging van de lichaamstemperatuur gemeten. Tijdens het onderzoek van het perineum viel meteen een wekedelenmassa op die uitpuilde tussen de vulvalippen (Figuur 1). Het ging om een vergrote clitoris. Het uitpuilend deel was licht geïrriteerd en uitgedroogd, maar niet geërodeerd. De vulva zelf had een normale grootte en was normaal gepositioneerd. Het vaginaal toucher bracht geen andere afwijkingen aan het licht.

Aangezien er irritatie van de afwijkende clitoris was, werd een clitorisresectie aangeraden. De eigenaars wensten niet te fokken en dus werd gelijktijdige gonadectomie geadviseerd. Voor de operatie werd een perifere intraveneuze (IV) katheter geplaatst in de vena cephalica. De hond werd IV gepremediceerd met dexmedetomidine $1 \mu \mathrm{g} / \mathrm{kg}$ (Dexdomitor, Orion Corporation, Finland) en methadon $0,2 \mathrm{mg} / \mathrm{kg}$ (Comfortan, Eurovet Animal Health BV, Nederland). Als inductiemiddel werd propofol (Propovet Multidose, Abbott Laboratories Ltd, Engeland) op effect toegediend. Een endotracheale tube werd ingebracht om de anesthesie met gassen te onderhouden.

De hond werd in rugligging gepositioneerd. Het abdomen werd op standaardwijze geopend door middel van een middellijnincisie vanop de umbilicus tot aan het os pubis. Bij inspectie van het genitaalstelsel viel op dat de gonaden zich situeerden aan de craniale polen van de nieren. Ter hoogte van de linkergonade waren de epididymis, de plexus pampiniformis en het gubernaculum testis macroscopisch herkenbaar. Ter hoogte van de rechtergonade waren de plexus pampiniformis en het gubernaculum testis herkenbaar. De epididymis was niet herkenbaar maar craniaal van de rechtergonade was een macroscopisch onherkenbare ovale structuur aanwezig. De twee gonaden waren verbonden met een macroscopisch normale baarmoeder die overging in een cervix. Na inspectie werden de bloedvaten craniaal van de gonaden dubbel geligeerd met poliglecaprone 25 2/0 (Monocryl, Ethicon, Verenigde Staten). De baarmoeder werd ter hoogte van de cervix dubbel geligeerd met Monocryl 2/0. Het
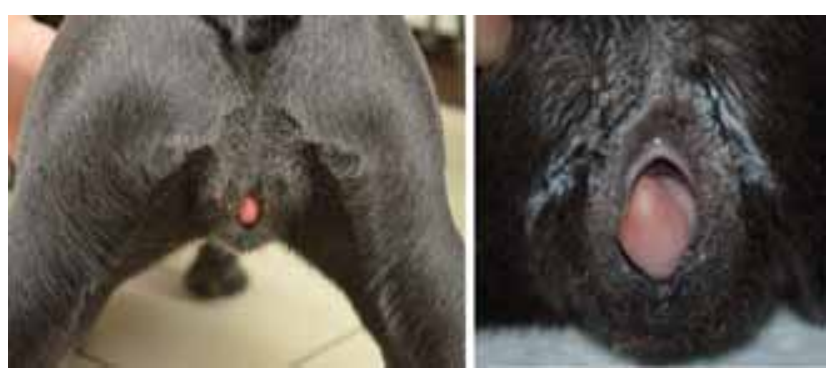

Figuur 1. Achteraanzicht van een tien maanden oude, vermeend vrouwelijke, intacte Franse buldog. De vergrote clitoris puilt permanent uit tussen de vulvalippen. 


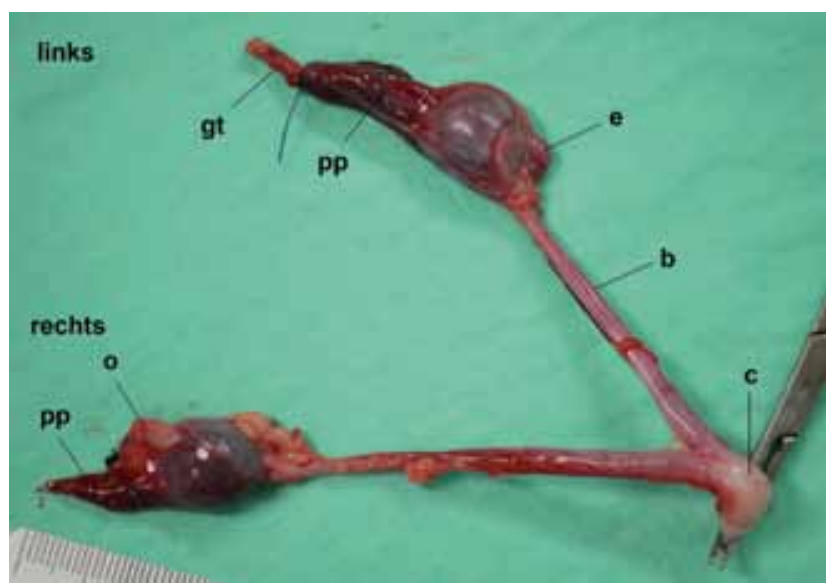

Figuur 2. Macroscopisch beeld van het verwijderde, genitale stelsel van de jonge Franse buldog met vergrote clitoris. Ter hoogte van de linkergonade zijn de epididymis (e), de plexus pampiniformis (pp) en het gubernaculum testis (gt) herkenbaar. Ter hoogte van de rechtergonade zijn ook de plexus pampiniformis (pp) en het gubernaculum testis herkenbaar. De epididymis is niet herkenbaar maar craniaal van de gonade is een ovale structuur (o) aanwezig. De twee gonaden zijn verbonden met een macroscopisch normaal uitziende baarmoeder (b), die caudaal overgaat in een cervix (c).

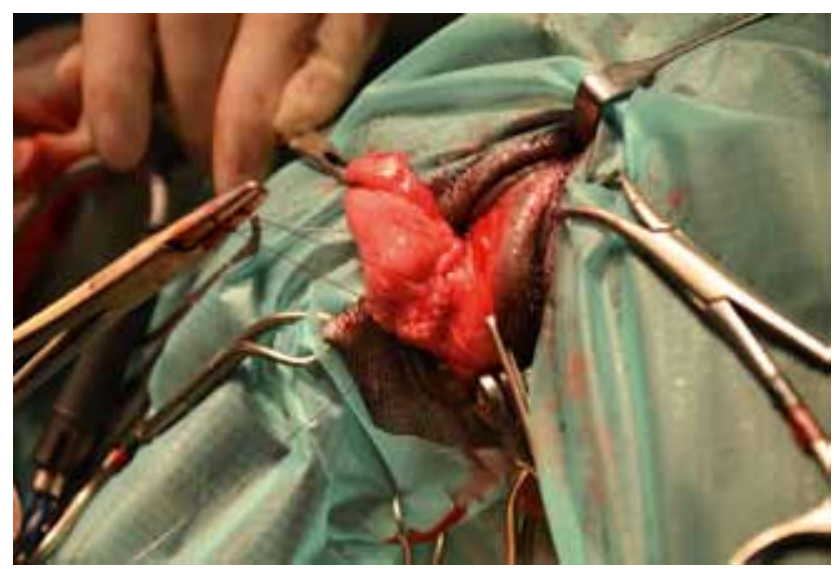

Figuur 3. Aangezien er irritatie van de afwijkende clitoris was, werd een clitorisresectie aangeraden. De vaginale mucosa rondom de clitoris werd stapsgewijs ingesneden om het afwijkende weefsel ter hoogte van de fossa clitoridis te isoleren. Vervolgens werd het afwijkend clitorisweefsel vrijgeprepareerd van de rest van de vaginale wand. onderbonden deel van het genitale stelsel werd als geheel verwijderd (Figuur 2). Hierna werd het abdomen routinematig gesloten. De buikwand werd doorlopend appositioneel gehecht met polydiaxanone 2/0 (PDSII, Ethicon, Verenigde Staten), de subcutis werd gesloten met een doorlopende matrashechting met Moncryl $3 / 0$ en de huid werd intradermaal gehecht, eveneens met Monocryl 3/0.

Aansluitend op de gonadohysterectomie werd een resectie van de vergrote clitoris uitgevoerd (Figuur 3 en 4). Hiervoor werd de hond in perineale positie gebracht en werd een beursnaad op de anus geplaatst. De uitmonding van de urethra werd geïdentificeerd door middel van een urinaire katheter en bevond zich op de anatomisch verwachtte positie. De vaginale mucosa rondom de clitoris werd stapsgewijs ingesneden om het afwijkende weefsel ter hoogte van de fossa clitoridis te isoleren. Vervolgens werd het vrijgeprepareerd van de rest van de vaginale wand. Ter hoogte van het dorsale deel van het afwijkende clitorisweefsel werd een duidelijke harde tubulaire streng gevoeld die zich naar craniaal verderzette. Tenslotte werd de ventrale plooi losgesneden van de vaginawand. De laterale bloedvaten werden geligeerd met Monocryl $3 / 0$, waarna het afwijkende weefsel weggesneden werd. Daarna werd de bodem van het vestibulum vaginalis met een doorlopende, appositionele hechting met Monocryl 3/0 gesloten. De urinaire sonde werd onmiddellijk postoperatief verwijderd.

De recovery verliep vlot en de dag nadien was de hond alert en levendig. De buikwand was droog en gesloten, de vulva iets gezwollen. Tot dag vijf postoperatief werd een lichte, fecale incontinentie vastgesteld, vermoedelijk omwille van de epidurale.

\section{Histologisch onderzoek}

Zowel het verwijderde deel van het genitale stelsel als de clitoris werd histopathologisch onderzocht. Op zowel een weefselstaal van de linker- als de rechtergonade werd een immature testis in combinatie met het beeld van een plexus pampiniformis gezien (Figuur 5). Er werd beiderzijds geen ovariumweefsel waargenomen. Aan de caudale pool van de gonaden wer-
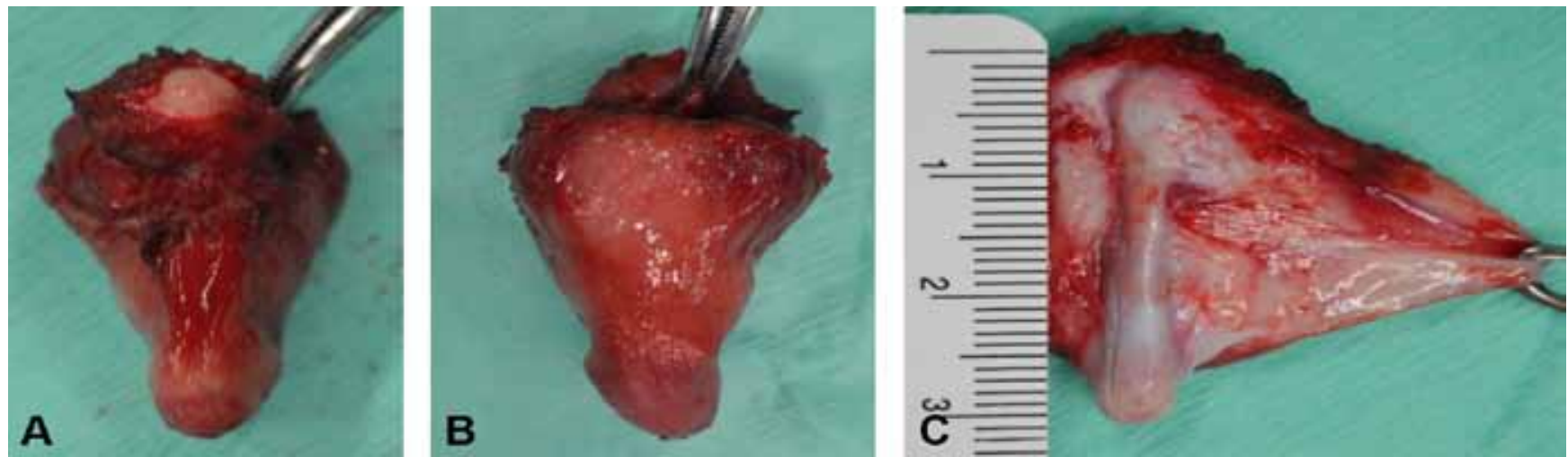

Figuur 4. Resectie van de vergrote clitoris. A. Dorsale aspect. B. Ventrale aspect. C. Longitudinale incisie in het dorsale deel. 

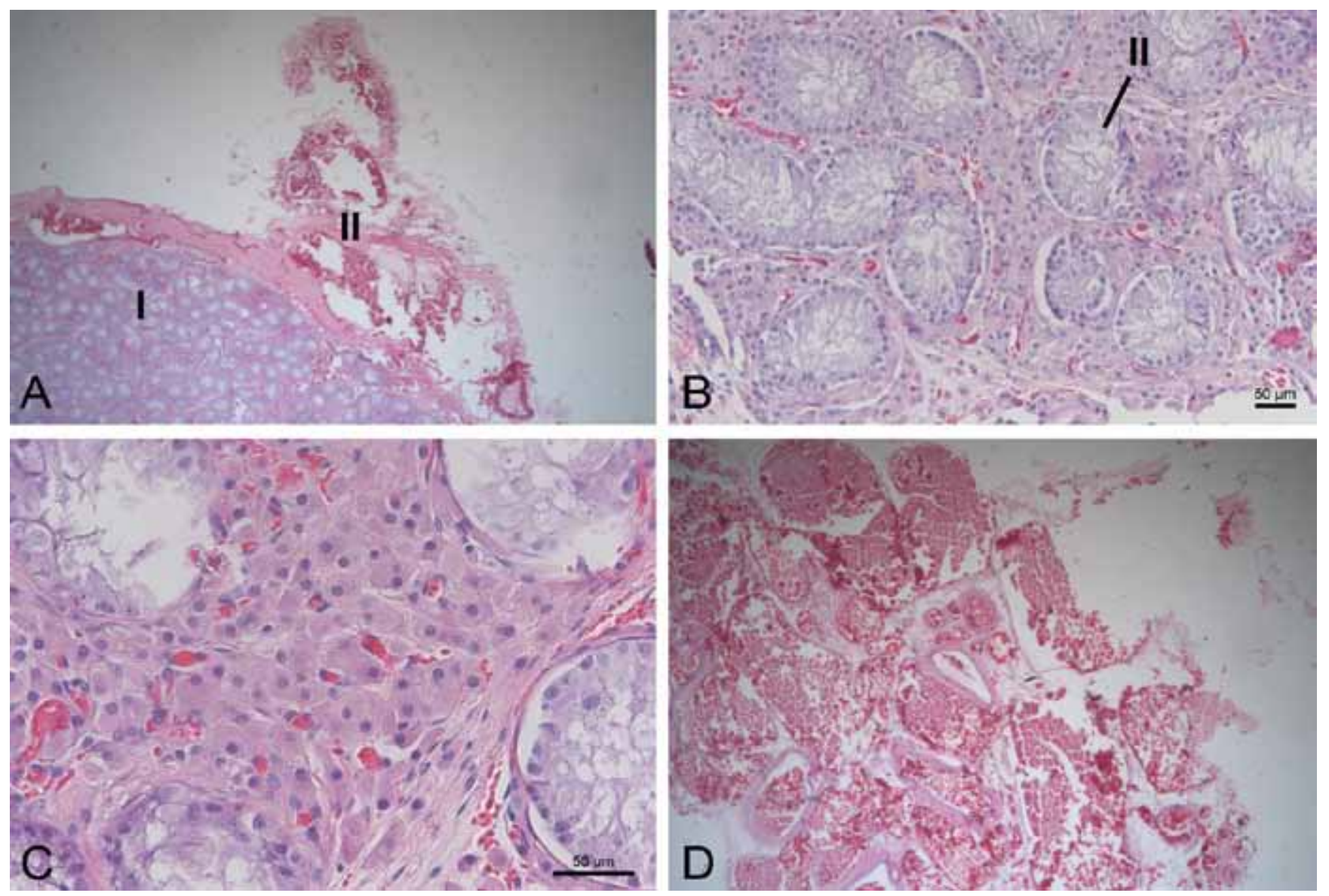

Figuur 5. A. Overzicht van de immature testis (I) en plexus pampiniformis (II) (vergroting 2,5x). B. Detail van de immature testis. De verschillende lobuli bevatten vele doorsneden doorheen de tubuli seminiferi (III). De tubuli seminiferi zijn afgelijnd met een eenlagig, hoogcylindrisch epitheel en bevatten een nauw lumen dat leeg is (vergroting 20x). C. Tussen de tubuli seminiferi zijn er de interstitiële leydigcellen aanwezig (vergroting 40x). D. Plexus pampiniformis met verschillende doorsneden doorheen arteriën en venen (vergroting $5 x$ ).
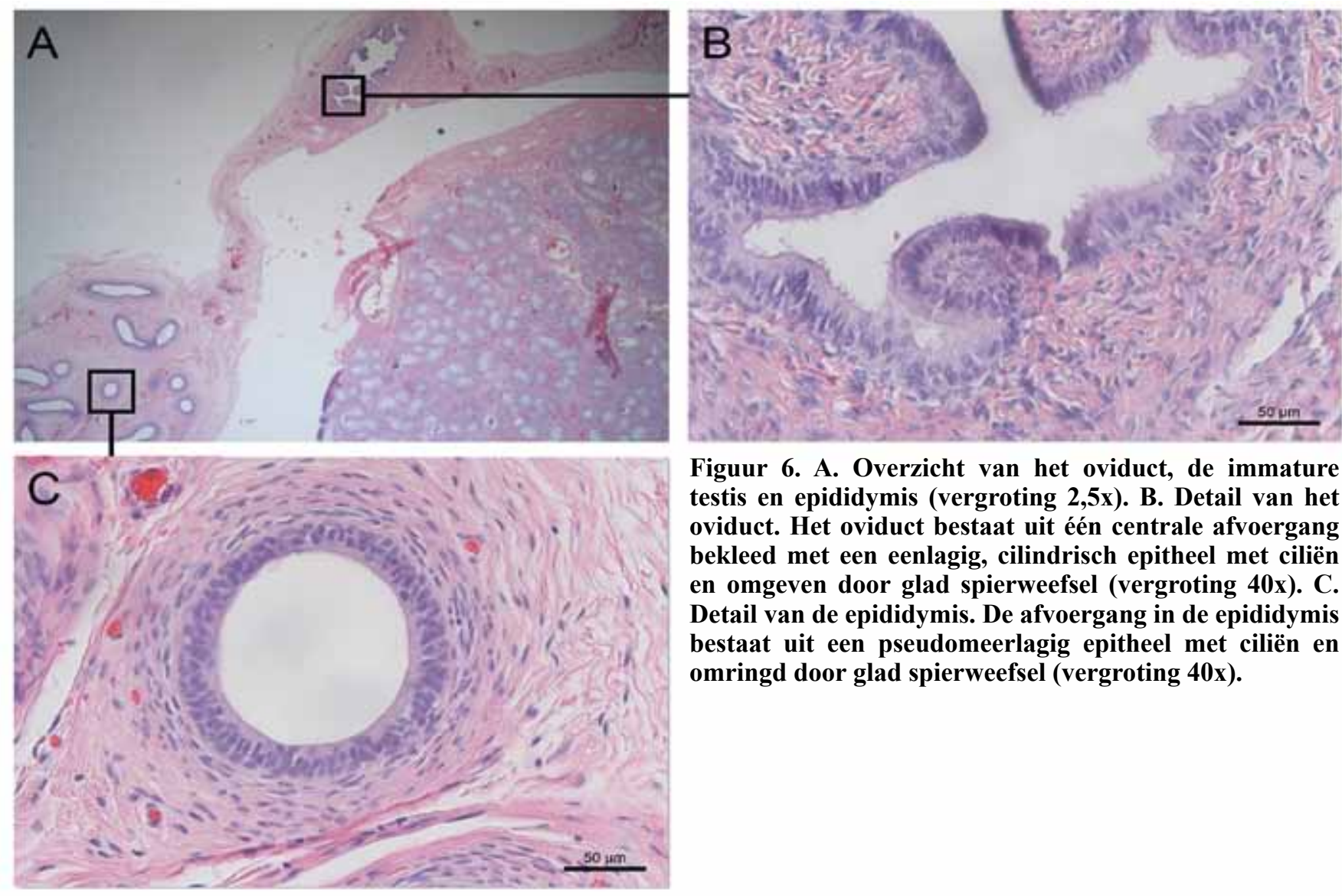

Figuur 6. A. Overzicht van het oviduct, de immature testis en epididymis (vergroting $2,5 x$ ). B. Detail van het oviduct. Het oviduct bestaat uit één centrale afvoergang bekleed met een eenlagig, cilindrisch epitheel met ciliën en omgeven door glad spierweefsel (vergroting 40x). C. Detail van de epididymis. De afvoergang in de epididymis bestaat uit een pseudomeerlagig epitheel met ciliën en omringd door glad spierweefsel (vergroting 40x). 

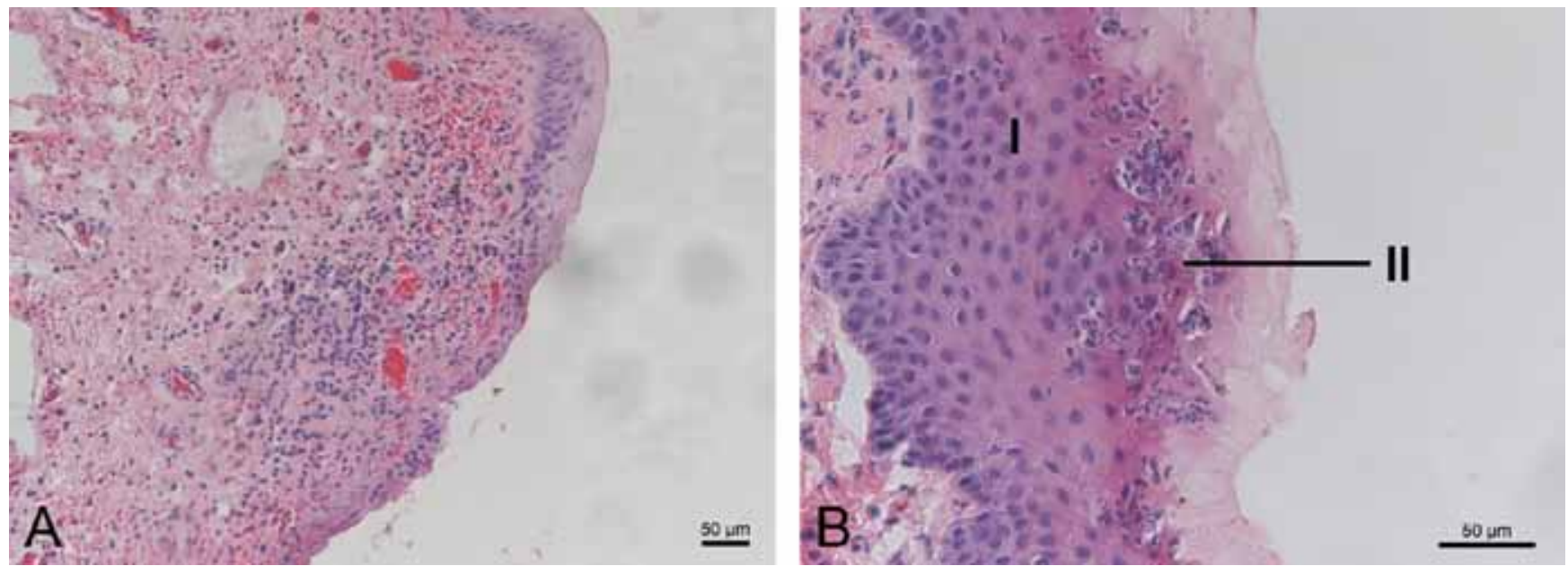

Figuur 7. A. Dwarse coupe van de clitoris (vergroting 20x). B. Detail van de clitoris, waarbij het weefsel bestaat uit een meerlagig, verhoornd epitheel (I) met multifocale erosies. In de onderliggende dermis is er een matige infiltratie (II) van lymfocyten, plasmacellen en neutrofielen.

den een epididymis, twee doorsneden doorheen een oviduct en een immature testis onderkend (Figuur 6). Er kon geen tubulo-uteriene junctie in beeld gebracht worden. Het lumen van de uterus was afgelijnd met afgeplatte tot kubische epitheelcellen en er was een gering aantal endometriale klieren aanwezig. Dit beeld was compatibel met een uterus in anoestrus. Het clitorisweefsel was afgelijnd met een meerlagig, verhoornd epitheel dat op vele plaatsen geülcereerd was (Figuur 7). Lokaal was er dan een infiltratie van lymfocyten, plasmacellen en neutrofielen. Er werd geen kraakbeenweefsel noch botweefsel gezien.

Chromosomale analyse en moleculaire studie van het $S R Y$-gen

Er werd $6 \mathrm{ml}$ bloed genomen uit de vena cephalica. Dit bloed werd verdeeld over twee bloedbuisjes: $4 \mathrm{ml}$ voor het heparinestaal, waarop de chromosomale analyse gebeurde en $2 \mathrm{ml}$ voor het EDTA-staal, waarop de moleculaire studie van de $S R Y / Z F Y$-genen gebeurde. De chromosomale analyse, door middel van giemsabanding, toonde een normaal vrouwelijk karyotype $(78, \mathrm{XX})$ (Figuur 8). Er kwamen geen chromosomale herschikkingen betreffende het X-chromosoom voor. Er werd ook een FISH ("fluorescence in situ hybridization") uitgevoerd met locusspecifieke sonden voor $\mathrm{Xp}$ (regio van de korte arm, $M A O-A$-gen) en Xq (regio van de lange arm, $A R$-gen). Dit werd gedaan om eventuele translocaties op te merken. De test toonde echter aan dat beide X-chromosomen een normale morfologie bezaten en er geen translocaties aanwezig waren.

Aan de hand van de polymerasekettingreactietechniek (PCR) werd de afwezigheid van het Y-gebonden SRY-gen ("sex determing region") aangetoond (Figuur 9). Hiervoor werd gebruik gemaakt van de volgende primers: 5'CTTTCCAACTTCCCTC-
CGTA en 5' GGACGTTTCGTTAGCCAGAG. De lengte van de PCR-producten waren 813 baseparen lang (Switonski et al., 2012). Het Y-gebonden SRYgen is van belang tijdens de seksuele ontwikkeling en is een bepalende factor in de ontwikkeling van de testis. Translocatie van het $S R Y$-gen op een niet-Ychromosoom kan leiden tot de ontwikkeling van een testikel bij een XX-individu (Campos et al., 2011). De afwezigheid van $Z F Y$ ("zinc finger Y-chromosomal gen”), een tweede Y-chromosoomgebonden gen, werd

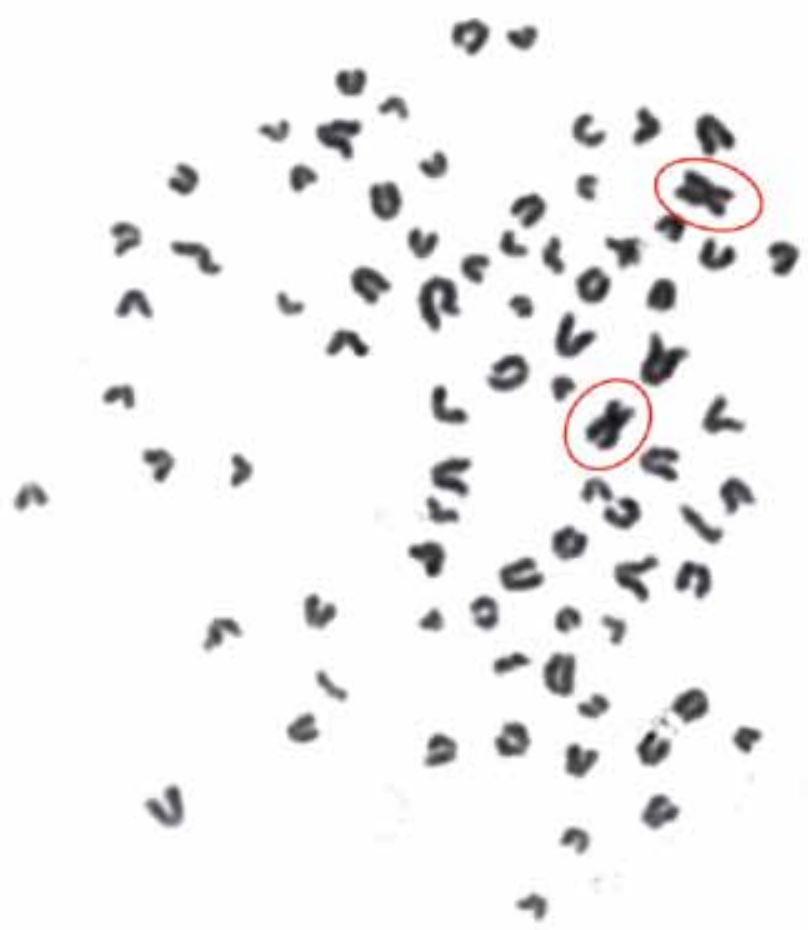

Figuur 8. Chromosomale analyse van de chromosomen in metafase na giemsakleuring, toont een normaal vrouwelijk karyotype aan $(78, X X)$. In deze figuur zijn de geslachtschromosomen, hier twee $\mathrm{X}$-chromosomen, omcirkeld. 

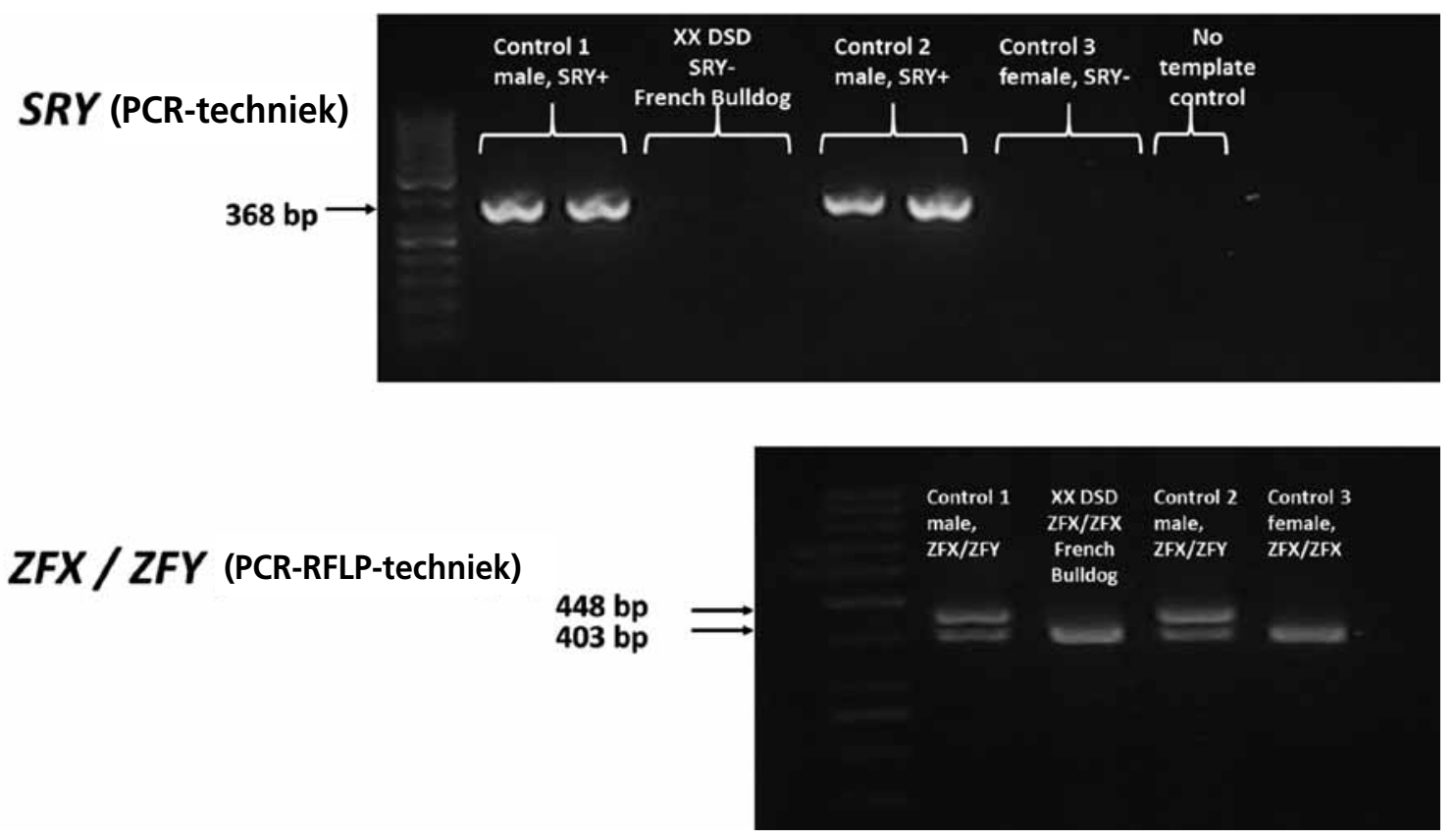

Figuur 9. Door de PCR (RFLP)-techniek werd de afwezigheid van Y-gelinkte genen, zoals het $S R Y$-gen en $Z F Y$-gen, aangetoond.

eveneens aangetoond door middel van PCR. Hiervoor werden de volgende primers gebruikt: 5' ATAATCACATGGAGAGCCACCAGCT en 5' GCACTTCTTTGGTATCTGAGAAAGT. De PCR-producten hadden een lengte van 448 baseparen. Door middel van PCRRFLP ("restriction fragment length polymorphism") werd aangetoond dat er geen $Z F Y$-gen maar een "zinc finger X-linked gene" ( $Z F X$-gen) aanwezig was. De PCR-producten van 448 baseparen werden verwerkt door middel van het HaeIII-restrictie-enzym. De bekomen producten waren 403 en 45 baseparen voor het $Z F X$-gen (Senese et al., 1999).

\section{DISCUSSIE}

De Franse buldog in deze casus werd aangeboden met de klacht van een vergrote clitoris en purulente, vaginale uitvloei. Clitoromegalie is een vaak voorkomend symptoom van interseksualiteit (Ettinger, 1983; Campos et al., 2011). De afwijking wordt meestal vastgesteld rond de leeftijd van zes maanden (Edward Allen, 1992). Bij de besproken hond werd de vergrote clitoris al op de leeftijd van acht weken opgemerkt. Naast interseksualiteit kan clitoromegalie ook veroorzaakt worden door de invloed van endogene of exogene androgenen (Ettinger, 1983). Hyperadrenocorticisme of de ziekte van Cushing wordt gekenmerkt door een overmaat aan cortisolproductie door de bijnieren. Hoewel deze ziekte een vergrote clitoris kan veroorzaken ten gevolge van een overmatige productie van androgenen, was dit allicht niet de oorzaak bij deze Franse buldog. Cushing komt namelijk zelden voor bij honden jonger dan één jaar en geeft een reeks aan klinische symptomen die deze patiënt niet had, namelijk polydipsie, polyurie, polyfagie, abdominale distentie, spierzwakte, lethargie en vachtveranderingen. Daarnaast kunnen ook exogene androgenen aanleiding geven tot een vergrote clitoris (Ettinger, 1983). Deze kunnen toegediend worden aan het moederdier tijdens de dracht of aan het jonge dier zelf. Wanneer exogene androgenen of progesteron gegeven worden aan de drachtige teef, dan resulteert dit in masculinisatie van alle vrouwelijke nakomelingen (Olson et al., 1989; Meyers-Wallen, 2011; England, 2013). Aangezien de vrouwelijke nestgenoot van de patiënt geen afwijkingen vertoonde, was de toediening van androgenen of progesteron aan het moederdier minder waarschijnlijk. Door de anamnese werd ook uitgesloten dat er androgenen of progesteron aan het jonge dier gegeven werden nadat het door de eigenaar in huis werd genomen. Interseksualiteit was daarom de meest waarschijnlijke oorzaak voor de vergrote clitoris. Dit werd bevestigd na de celiotomie en de histologie van de gonaden.

Indien er niet meteen duidelijke tekenen aanwezig zijn, is het stellen van de diagnose van interseksualiteit niet altijd evident. De meeste honden worden aangeboden met externe genitalia die er afwijkend uitzien. In andere gevallen worden ze aangeboden met onvruchtbaarheid of het uitblijven van de oestrus. Wanneer de externe genitalia licht afwijkend zijn, dan kan de diagnose moeilijk worden (Poth et al., 1976). Voor de diagnose is het belangrijk om zowel het fenotypische geslacht, de gonadale constitutie en de chromosomale constitutie met eventueel moleculaire analyse van Y-gebonden genen te kennen. In een eerste fase wordt het fenotypische geslacht bepaald. De Franse buldog in deze casus werd aangeboden met clitoromegalie en groengele, vaginale uitvloei. Ook in 
de literatuur wordt beschreven dat interseksen vaak initieel aangeboden worden met een vergrote clitoris (Alam et al., 2007; Lyle, 2007; Bigliardi et al., 2011). De beschreven hond had een normale macroscopische vulva die gelegen was op de normale anatomische locatie. Bij deze hond was het fenotypische geslacht dus vrouwelijk. De volgende stap was het identificeren van de gonadale constitutie door histopathologisch onderzoek van de gonaden. Enkel zo kan een definitieve diagnose gesteld worden. Indien gewenst kan preoperatief een echografie van het abdomen uitgevoerd worden, maar vaak wordt meteen tot een gonadectomie overgegaan (Chayhan et al., 2008). Dit was ook in deze casus het geval. Bij de Franse buldog waren er bilaterale testes aanwezig die aansloten op een normale baarmoeder. Het clitorisweefsel toonde heel wat ulceraties en irritatie. Het bevatte geen kraakbeenweefsel, hoewel dit macroscopisch verwacht werd. De derde stap was het bepalen van de chromosomale constitutie. Hiervoor moest het karyotype bepaald worden. Karyotypering levert informatie op betreffende de chromosoomaantallen en globale chromosoomstructuur (Poth et al., 2010). De Franse buldog in deze casus bleek een 78, XX chromosomale constitutie te hebben. Bijkomend werd door middel van een PCR-test de aanwezigheid van Y-gebonden genen nagegaan. Zowel het SRY- en $Z F Y$-gen waren beide afwezig. Volgens de Chicago Consensus wordt de Franse buldog geclassificeerd als een 78, XX SRYnegatieve testiculaire DSD. Vroeger werd dit aangeduid als een "XX sex reversal" (XX-geslachtsomkering). "Sex reversal" is een congenitale afwijking, waarbij de gonadale en chromosomale constitutie niet overeenstemmen. XX sex reversal-individuen kunnen XX mannelijk zijn met bilaterale testes, zoals in deze casus, of XX ware hermafrodiet met ovotestes (Campos et al., 2011; Silversides et al., 2011). De aandoening wordt gerapporteerd bij honden, varkens, geiten, paarden en bij de mens. Bij de mens komt 46,XX testiculaire DSD voor met een frequentie van 1 op 20.000 geboorten (Ergun-Longmire et al., 2005; Campos et al., 2011). Tien procent van deze individuen is $S R Y$-negatief (Campos et al., 2011). Bij de hond wordt 78,XX testiculaire DSD beschreven bij tenminste 20 rassen, hoewel de prevalentie ervan binnen de rassen niet eenduidig in de literatuur te vinden is. Vele beschreven gevallen zijn $S R Y$-negatief (Campos et al., 2011; Silversides et al., 2011). De directe oorzaak van 78,XX $S R Y$-negatieve, testiculaire DSD en de manier van overerven worden volop onderzocht (Silversides et al., 2011; Max et al., 2012; Rossi et al.,2014). Bij de Amerikaanse cockerspaniël werd bevestigd dat het om recessieve overerving gaat, maar bij andere rassen wordt dat enkel verondersteld (Kuiper et al., 2005; Meyers-Wallen, 2006). Het is niet bekend of de oorzakelijke mutatie(s) bij de verschillende rassen hetzelfde is, ook niet of het om een of meerdere genen gaat. Recent werd er in een studie met zeven honden een oorzakelijk gen voor 78, XX testiculaire DSD gevonden. Bij twee van de zeven honden werd een duplicatie van het $S O X 9$-gen ontdekt. Dit gen wordt bij XY-individuen door het $S R Y$-gen geactiveerd, waardoor de ontwikkeling van uiteindelijke testes start. Het is niet bekend waarom het SOX9-gen gedupliceerd was bij de onderzochte honden (Rossi et al., 2014). Er wordt nog steeds getracht andere gemuteerde gen(en) bij de hond te identificeren (MeyersWallen, 2006; Silversides et al., 2011). In de literatuur werden twee gevallen van 78,XX $S R Y$-negatieve, testiculaire DSD bij de Franse buldog beschreven (Campos et al., 2011; Silversides et al., 2011). Het feit dat dit bij hetzelfde ras voorkomt, kan toevallig zijn, maar het is anderzijds niet uitgesloten dat 78, XX SRY-negatieve, testiculaire DSD familiaal kan zijn bij de Franse buldog (Silversides et al., 2011). Indien het effectief om een autosomaal recessieve aandoening gaat, dan kunnen de ouderdieren asymptomatische dragers zijn. Het onderkennen van dergelijke dragers is belangrijk om de verspreiding van het (de) gemuteerde gen(en) in het ras te vermijden. Bovendien is het onderzoeken van het (de) gemuteerde oorzakelijk gen(en) ook van belang om deze aandoening bij de mens beter te vatten (Campos et al., 2011). SRY-negatieve honden kunnen mogelijk dienen als diermodel voor de mens (Hubler et al., 1999).

Het is aangeraden om een gonadohysterectomie uit te voeren bij dieren met DSD. Dit voorkomt dat er zich testisneoplasie ontwikkelt. XX-individuen met testes zijn steriel, maar XX-individuen met ovotestes kunnen fertiel zijn (Lyle, 2007; Meyers-Wallen, 2009; Poth et al., 2010). Bij deze individuen wordt er door gonadohysterectomie ook voorkomen dat de dieren zich kunnen voortplanten en zo het(de) gemuteerde gen(en) verspreiden. In dit opzicht is het aan te raden om naast de aangetaste, testiculaire DSD-dieren ook de ouderdieren en nestgenoten te weren uit de fok. Deze kunnen namelijk asymptomatische dragers zijn en nietsvermoedend het (de) gemuteerde gen(en) verspreiden (Lyle, 2007; Meyers-Wallen, 2009).

Het belang van aandoeningen van seksuele differentiatie is groot voor zowel de hond als de mens. Verder onderzoek zal hopelijk het (de) oorzakelijke gen(en) van 78,XX testiculaire DSD aanduiden om zo te dienen als humaan studiemodel en om de aandoening bij de hond te elimineren. Wanneer de overerving en de genetische oorzaak beter bekend zijn, kunnen er in de toekomst hopelijk DNA-testen voor de opsporing van dragers ontwikkeld worden. In dit opzicht is het belangrijk dat dierenartsen, onderzoekers en fokkers het vermoeden van interseksualiteit rapporteren.

\section{REFERENTIES}

Alam MR, Cho YG, Cho SJ, Lee JI, Lee HB, Tae HJ, Kim IS, Kim NS. (2007). Male pseudohermaphroditism in dogs: three case reports. Veterinary Medicine 52, 74-78.

Bigliardi E, Parma P, Peressotti P, De Lorenzi L, Wohlsein P, Passeri B, Jottini S, Cantoni AM. (2011). Clinical, genetic, and pathological features of male pseudoherma- 
phroditism in dog. Reproductive Biology Endocrinoly 9, 12.

Campos M, Moareno-Manzano V, Garcia-Rosello M, Garcia-Rosello E. (2011). SRY-negative XX sex reversal in a French Bulldog. Reproduction in Domestic Animals 46, 185-188.

Chayhan GB, Parra DA, Oudjhane K, Miller SF, Babyn PS, Pippi Salle JL. (2008). Imaging of ambiguous genitalia: classification and diagnostic approach. Radiographics 28,1891-1904.

Edward Allen W. (1992). Fertility and Obstetrics in the Dog. First edition, Blackwell Scientific Publications. Oxford, p104.

England GCW. (2013). Dog Breeding, Whelping and Puppy Care. First edition, Wiley-Blackwell. Ames, Iowa, p296

Ergun-Longmire B, Vinci G, Alonso L, Matthew S, Tansil S, Lin-Su K, McElreavey K, New MI. (2005). Clinical, hormonal and cytogenetic evaluation of $46, \mathrm{XX}$ males and review of the literature. Journal of Clinical Endocrinology and Metabolism 18(8),739-748.

Ettinger SJ. (1983) Textbook of Veterinary Internal Medicine: Diseases of the Dog and Cat, volume II. Second edition, WB Saunders. Philadelphia, p 1674-1680.

Hare WCD. (1976). Intersexuality in the dog. The Canadian Veterinary journal 17, 7-15.

Hubler M, Hauser B, Meyers-Wallen VN, Arnold S. (1999). $S R Y$-negative XX true hermaphrodite in a Basset Hound. Theriogenology 51, 1391-403.

Kuiper H, Bunck C, Günzel-Apel AR, Drögemüller C, Hewicker-Trautwein M, Distl O. (2005) SRY-negative XX sex reversal in a Jack Russell Terrier: a case report. The Veterinary Journal 169, 116-117.

Lee PA, Houk CP, Ahmed SF, Hughes IA. (2006). International Consensus Conference on Intersex organized by the Lawson Wilkins Pediatric Endocrine Society and the European Society for Paediatric Endocrinology. Consensus statement on management of intersex disorders. International Consensus Conference on Intersex. Pediatrics 118 , e488-e500.

Lyle SK. (2007). Disorders of sexual development in the dog and cat. Theriogenology 68, 338-343.

Max A, Grabiec A, Sacharczuk M, Sysa P, Jurka P, Krzyzewska A. (2012). 78, XX testicular DSD syndrome in a mongrel dog. Reproduction in Domestic Animals 47,e7e11.

Meyers-Wallen VN. (1999). Inherited disorders in sexual development. Journal of Heredity 90, 93-95.
Meyers-Wallen VN. (2006). Genetics, genomics, and molecular biology of sex determination in small animals. Theriogenology 66, 1655-1658.

Meyers-Wallen VN. (2009). Review and update: Genomic and molecular advances in sex determination and differentiation in small animals. Reproduction in Domestic Animals 44, 40-46.

Meyers-Wallen VN. (2011). Gonadal and sex differentiation abnormalities of dogs and cats. Sexual Development 6, 46-60.

Olson PN, Seim HB, Park RD, Grandy JL, Freshman JL, Carlson ED. (1989). Female pseudohermaphroditism in three sibling greyhounds. Journal of the American Veterinary Medical Association 194, 1747-1749.

Pasterski V, Prentice P, Hughes IA. (2010). Impact of the consensus statement and the new DSD classification system. Best Practices \& Research Clinical Endocrinology \& Metabolism 24, 187-195.

Poth T, Breuer W, Walter B, Hecht W, Hermanns W. (2010). Disorders of sex development in the dog - adoption of a new nomenclature and reclassification of reported cases. Animal Reproduction Science 121,197-207.

Rossi E, Radi O, De Lorenzi L, Vetro A, Groppetti D, Bigliardi E, Luvoni GC, Rota A, Camerino G, Zuffardi O, Parma P. (2014). SOX9 duplications are a relevant cause of sry-negative XX sex reversal dogs. PLoS ONE 9(7),e101244.

Senese C, Penedo MC, Shiue YL (1999) HaeIII PCR-RFLP in the ZFY/ZFX genes of horses. Animal Genetics 30, 390-391.

Silversides DW, Benoit J-M, Collard F, Gilson C. (2011). Disorder of sex development (XX male, SRY negative) in a French bulldog. Canadian Veterinary Journal 52, 670672.

Switonski M. (2014). Genetic background of canine and feline disorders of sexual development. In: Proceedings 17th EVSSAR congress.

Switonski M, Payan-Carreira R, Bartz M. (2012) Hypospadias in a male (78, XY; SRY-positive) dog and sex reversal female (78, XX; SRY-negative) dogs: clinical, histological and genetic studies. Sexual Development 6, 128-134.

Volpe P, Izzo B, Di Meo GP, Perucatti A, Iannuzzi L. (2000). Male pseudo-hermaphroditism in a dog: a clinical case. Veterinary Record 146, 532-533. 